\title{
Whey starter addition during maturation of evening milk: effects on some characteristics of cheese milk and Parmigiano-Reggiano cheese
}

\author{
Fabio Coloretti ${ }^{1}$ - Cristiana Chiavari ${ }^{1}$. \\ Marco Nocetti ${ }^{2}$ - Paolo Reverberi ${ }^{2}$. \\ Elena Bortolazzo ${ }^{3} \cdot$ Valeria Musi $^{3} \cdot$ Luigi Grazia $^{1}$
}

Received: 16 April 2015 / Revised: 26 August 2015 / Accepted: 28 August 2015 /

Published online: 10 September 2015

(C) INRA and Springer-Verlag France 2015

\begin{abstract}
Cheese milk "maturation" during natural creaming in large flat vat is a critical step in the production of Parmigiano-Reggiano cheese. Thanks to an improved management, during the last years, a generalized reduction of mesophilic microbial counts has occurred, which did not favour an adequate increase in milk acidity during natural creaming. For this reason, some cheesemakers have introduced the practice to add a rate of natural whey starter in active fermentation in the evening milk to favourize its "maturation". The aim of this work was to verify the effects of this practice on the characteristics of Parmigiano-Reggiano milk and on some chemical, microbiological and sensory properties of the ripened cheese. Thirty-six cheesemaking trials were carried out in a dairy: 12 with $0.2 \%$ of young whey starter addition, 12 with $0.4 \%$ and 12 as control. The addition of young whey starter improved the coagulation properties of the cheese milk and did not affect the normal succession of thermophilic and mesophilic lactic acid bacteria during the cheese ripening. The chemical composition of the ripened cheeses was not affected by the practice of whey starter addition. From the sensory point of view, the addition of natural whey starter improved the compliance scores and decreased the defects, as eyes and cracks. This work confirmed the empirical observations of some cheesemakers. The adoption of this technique has considerable technological importance, improving the coagulation properties of the milk and the sensory characteristics of the cheese.
\end{abstract}

Fabio Coloretti

fabio.coloretti@unibo.it

1 Dipartimento di Scienze e tecnologie Agroalimentari (DISTAL), Alma Mater Studiorum Università di Bologna, Via F.lli Rosselli, 107, 42123 Reggio Emilia, Italy

2 Consorzio del Formaggio Parmigiano Reggiano, Via JF Kennedy, 18, 42124 Reggio Emilia, Italy

3 C.R.P.A. S.p.A. - Centro Ricerche Produzioni Animali, Viale Timavo, 43/2, 42121 Reggio Emilia, Italy 
Keywords Parmigiano - Reggiano - Natural whey starter Evening milk Milk maturation · NSLAB

\section{Introduction}

Parmigiano-Reggiano (PR) is a Protected Designation of Origin (PDO) Italian hard, cooked cheese, obtained from partially skimmed raw cow milk and characterized by a slow and long ripening. Cheese milk, with $2.2-2.5 \%$ fat, is a mixture of the evening milk, which is partially skimmed by natural creaming, and of the morning whole milk. It is then poured into a vat and heated at about $22^{\circ} \mathrm{C}$; natural whey starter is added at a ratio of approximately $2.8-3.0 \%$, resulting in approximate acidity of $4.2-4.5^{\circ} \mathrm{SH} .50 \mathrm{~mL}^{-1}$. Coagulation occurs at $32-33{ }^{\circ} \mathrm{C}$ after the addition of calf rennet powder (www. parmigiano-reggiano.it). Natural whey comes from the previous day cheesemaking. Its incubation starts at $52-54{ }^{\circ} \mathrm{C}$ and ends $20 \mathrm{~h}$ later at $27-30{ }^{\circ} \mathrm{C}$. Its final acidity ranges from 25 to $30^{\circ} \mathrm{SH} .50 \mathrm{~mL}^{-1}$ (Sacchetti and Zambonelli 1963; Reverberi et al. 2009; Mucchettti et al. 2014). Whey starter addition increases milk acidity and enriches the milk with live cells, represented mainly by thermophilic lactic acid bacteria, symbolized as starter lactic acid bacteria (SLAB), represented by thermophilic and homofermentative species, as Lactobacillus helveticus and L. delbrueckii ssp. bulgaricus/lactis. Facultatively, homofermentative species, as L. rhamnosus, heterofermentative species, as L. fermentum, L. brevis, and Streptococcus thermophilus, are often included (Coppola et al. 2000; Gatti et al. 2014).

The natural creaming of evening milk is a fundamental step to optimize the fat/casein ratio of vat milk that should range from 0.95 to 1.10 (Mariani et al. 2001). As reported in the Production Specification, natural creaming must be conducted, overnight, at a temperature not less than $18{ }^{\circ} \mathrm{C}$ (EU 2011; www.parmigiano-reggiano.it). The separation of milk fat globules occurs during the natural creaming process and reduce the fat content of about 35-45\%, reaching at the end approximately $1.7-1.8$ g. $100 \mathrm{~mL}^{-1}$ (Malacarne et al. 2008). The microbial count at the end of this process depends on two contrasting factors: active growth of microorganisms and their migration into the cream due to the adhesion of the cells to milk fat globules. So, in many cases, the microbial count of the skimmed milk is lower than that of the evening milk (Panari et al. 2007).

Mesophilic lactic acid bacteria, derived from raw milk, can grow under the conditions of natural creaming. They are called Non Starter Lactic Acid Bacteria (NSLAB) (Gripon et al. 1975; Coppola et al. 2000; Neviani et al. 2009) and are involved in a number of biological modifications, both as live cells or after autolysis, when releasing enzymes that contribute to the cheese ripening. NSLAB are present at significant levels after 1 month of ripening, replacing thus the thermophilic LAB added with the natural whey starter (SLAB). The SLAB are active in the early days acidifying the curd. Then, the consumption of lactose and the decrease of ripening temperature limit their growth, favouring cells autolysis. Enzymes released by SLAB induce the production of compounds essential for NSLAB metabolism (Gatti et al. 2008).

In the last 20 years, dairies have introduced the conditioning of natural creaming rooms to avoid seasonal effect on the PR cheesemaking (Pecorari and Panari 2005). During summer, high temperatures favour the microbial growth, increasing the milk titratable acidity, and under these conditions, rennet clotting behaviour is appropriate. 
On the other hand, during winter, the curd characteristics are inferior (Malacarne et al. 2008). Room conditioning and improved management of hygiene both led to a reduction of the mesophilic microbial count below 100,000 CFU . mL ${ }^{-1}$ (Reg. EC 853/2004, EU 2004), which do not favour an adequate increase in milk acidity during natural creaming.

According to many cheesemakers, during this step, the milk does not mature properly (Desmazeaud 1984), which can result in unsuitable curd properties (Malacarne et al. 2008). To avoid these problems and to facilitate a proper "maturation" of milk during natural creaming, Mr. Oriano Carretti and other cheesemakers have introduced the practice to add a rate of natural whey starter in active fermentation to the evening milk. When adding, the young whey starter, fermented for 6-8 h, shows a titratable acidity of approximately $15-16^{\circ} \mathrm{SH} .50 \mathrm{~mL}^{-1}$ and a $\mathrm{pH}$ near 3.50 . A variable rate (around $0.3 \%$ ) of natural whey starter can be added to the evening milk, before left for natural creaming. In this way, a high number of thermophilic LAB, a low number of mesophilic LAB and a small quota of lactic acid are added to the milk during the creaming. According to cheesemakers' experience, this technique improves the rheological characteristics of vat milk and also the quality of the ripened cheese.

In the absence of scientific evidences, the aim of this work was to verify the effects of the whey starter addition into the evening milk on the characteristics of ParmigianoReggiano cheese milk and on some chemical, microbiological and sensory properties of the ripened cheese.

\section{Materials and methods}

\subsection{Experimental cheesemaking}

Thirty-six cheesemaking trials, in four different days (nine trials/day) were carried out in a dairy producing Parmigiano-Reggiano cheese. Each day, $4500 \mathrm{~L}$ of evening milk was divided into three batches of $1500 \mathrm{~L}$ each and poured into three different large flat vats for natural creaming. In two of these vats, young natural whey starter, actively fermented for 6-8 h, was added at 0.2 (LW) and $0.4 \%$ (HW) ratios, respectively. The third vat was used as control (C). The next morning, the partially skimmed milk of each flat vat was equally distributed into three cheese vats and was mixed with $500 \mathrm{~L}$ of morning whole milk. Total production was 72 wheels of cheeses (two twin wheels per vat): 24 C, $24 \mathrm{LW}$ and $24 \mathrm{HW}$.

Cheesemaking was continued according to Production Specification, (EU 2011; www.parmigiano-reggiano.it). Briefly, the first step was addition of natural whey starter (about $3 \mathrm{~L}$ for $100 \mathrm{~L}$ of milk). The milk was heated in the vat to a temperature of $33{ }^{\circ} \mathrm{C}$, and calf rennet was added and the coagulation process began within 10 $12 \mathrm{~min}$. The curd was turned over and broken into small granules (size rice grains) ready for the cooking. In this step, the temperature increased from 33 to $55^{\circ} \mathrm{C}$ within 10 $15 \mathrm{~min}$. When the heat was turned off, the cheese granules precipitate toward the bottom of the vat, forming a solid mass. After about an hour, this mass was collected and cut into two twin wheels of approximately $40 \mathrm{~kg}$ and placed inside special moulds. After 2 days of cooling and drying, the wheels are salted by immersion in satured brine (around 23\%) for 21 days. From then onward, the cheese undergoes a long process of ripening for 22 months in a controlled store room at about $18{ }^{\circ} \mathrm{C}$ and $80 \%$ relative humidity. 
The technological quality of milks was blind-tested during cheesemaking by a cheesemaker of another dairy and two technicians.

\subsection{Sampling}

Milk samples were collected aseptically from evening milk, both before and after the whey starter addition, from partial skimmed milk and from vat milk. Samples of whey starter were collected during the fermentation in the evening, just at time of addition and at the end of fermentation, prior use in vat. At the end, the fresh whey after cooking was collected.

From each vat, two wheels were obtained and one was used for sampling. Cheeses were sampled for microbiological analyses at $48 \mathrm{~h}$ after vat extraction and at 7 and 12 months of ripening. For this purpose, a cheese core was aseptically extracted with a cheese drill, and the removed part of cheese was replaced by a sterile mixture of vaseline (30\%) and paraffin wax (70\%) (Instruments Lab Control, Reggio Emilia, Italy), liquefied at $60{ }^{\circ} \mathrm{C}$. At the end of ripening (22 months), in addition to microbiological analyses, chemical and sensory analyses were carried out. The wheel was cut to obtain two symmetrical half wheels, and a quarter of cheese wheel was divided into three subsamples for physico-chemical, microbiological and sensory analyses.

\subsection{Milk compositional and coagulation properties analyses}

Titratable acidity was determined using Soxhlet-Henkel method (Savini 1946) with $0.25 \mathrm{M} \mathrm{NaOH}$, and $\mathrm{pH}$ measurements were performed using a potentiometer (Crison Instruments, Barcelona, Spain). Fat and casein were measured by infrared analysis (Biggs 1978), with a Milko-Scan 134 A/B apparatus (Foss Electric, Hillerød, Denmark). Somatic cells count (SCC) and total bacteria count (TBC) were determined by fluorocytometry (Schmidt-Madsen 1975) with Fossamatic 5000 and Bactoscan 8000 apparatus, respectively (Foss Electric, Hillerød, Denmark).

Coagulation properties were assessed with a Formagraph apparatus (Foss Electric, Hillerød, Denmark) under isothermal conditions at $35{ }^{\circ} \mathrm{C}$ according to Annibaldi et al. (1977).

\subsection{Whey starter analyses}

Titratable acidity and $\mathrm{pH}$ were determined as reported above for the milk. The acidification rate was evaluated by Reverberi et al. (2009) method. For this purpose, the sample of whey $(1.5 \mathrm{~mL}$ ) was inoculated in $50 \mathrm{~mL}$ of skim milk (Oxoid), and the incubation was carried out at temperatures of 45 and $54{ }^{\circ} \mathrm{C}$. After $4 \mathrm{~h}$, the increase of titratable acidity was estimated: the acidification rate, at a specified temperature, was expressed as the difference between the final and initial acidity $\left(\Delta^{\circ} \mathrm{SH} .50 \mathrm{~mL}^{-1}\right)$.

\subsection{Cheese compositional analyses}

Moisture content was determined by drying the sample at $102{ }^{\circ} \mathrm{C}$ (IDF 4A 1982), and fat was measured using Gerber-Siegfeld method (Savini 1946). $\mathrm{NaCl}$ content was determined by titrating with $\mathrm{AgNO}_{3}$ (IDF 88A 1988) and lactic acid using an 
enzymatic test kit (R-Biopharm, Darmstadt, Germany). The total nitrogen (TN) and $\mathrm{pH}$ 4.6 soluble nitrogen (SN) values were obtained as described by Gripon et al. (1975), and their values were assessed using the Kjeldahl method. The ripening index was calculated from the ratio SN/TN. The water activity $\left(a_{W}\right)$ was measured using an AquaLab CX3-TE apparatus (Labo-Scientifica, Parma, Italy).

\subsection{Lactic acid bacteria counts}

Lactic acid bacteria (LAB) counts were determined in milk, whey starter and cheese samples. For this purpose, decimal dilutions in physiological solution $\left(9 \mathrm{~g} \cdot \mathrm{L}^{-1}\right.$ of $\mathrm{NaCl}$ ) were made and plated in MRS agar (Oxoid) and incubated anaerobically at $22{ }^{\circ} \mathrm{C}$ for $120 \mathrm{~h}$ for mesophilic LAB and at $45^{\circ} \mathrm{C}$ for $96 \mathrm{~h}$ for thermophilic LAB.

\subsection{Sensory analyses}

Cheese samples were tested by a panel of 10 assessors selected and trained according to the ISO 8586-1:1993 and ISO 8586-2:1994, and Quantitative Descriptive Analysis (QDA) was carried out. The preparation of the test and the evaluation of the products was according to the UNI EN ISO 13299:2010 "Sensory analysis-MethodologyGeneral Guidance for establishing a sensory profile". Sensory analysis was conducted in a controlled environment (laboratory CRPA Lab according to UNI ISO 8589:2010).

The applied sensory sheet included the following characteristics evaluated on a structured continuous scale of 7 points $(1=$ absence of sensation, $7=$ greatest intensity of sensation):

- Appearance attributes: colour intensity, colour uniformity, eyes/cracks numbers, eyes/cracks dimension, presence of micro-eyes, and appearance compliance score

- Olfactory attributes: smell intensity, butter smell, rind smell, boiled vegetable smell, nuts smell, negative smells, and olfactory compliance score

- Aroma and taste attributes: sweet, salty, bitter, pungent, butter aroma, rind aroma, nuts aroma, meat broth aroma, nutmeg aroma, negative aroma, aroma, and taste compliance score

- Textural attributes: elasticity, friability, moisture, solubility, presence of grain, and textural compliance score

\subsection{Statistical analyses}

Data were analysed by ANOVA using SPSS 17.0 (SPSS Inc., Chicago, IL, USA) software package. Significant differences between mean values were determined by Tukey's test.

\section{Results and discussion}

The analytical characteristics of young natural whey starter added to the evening milk at beginning of creaming are shown in Table 1. The titratable acidity 
Table 1 Chemical and microbiological characteristics of young natural whey starters (actively fermented for $6-8 \mathrm{~h})$ added to evening milk $(n=4)$

\begin{tabular}{lrlrr}
\hline Parameter & Mean & Standard deviation & Min & Max \\
\hline Titratable acidity $\left({ }^{\circ} \mathrm{SH} .50 \mathrm{~mL}^{-1}\right)$ & 16.52 & 0.95 & 15.40 & 18.60 \\
$\mathrm{pH}$ & 3.65 & 0.05 & 3.56 & 3.72 \\
Acidification rate at $45^{\circ} \mathrm{C}\left(\Delta^{\circ} \mathrm{SH} .50 \mathrm{~mL}^{-1}\right)$ & 4.01 & 1.00 & 2.49 & 5.53 \\
Acidification rate at $54^{\circ} \mathrm{C}\left(\Delta^{\circ} \mathrm{SH} .50 \mathrm{~mL}^{-1}\right)$ & 1.47 & 0.14 & 1.28 & 1.68 \\
Mesophilic LAB $\left(\log \mathrm{CFU} \cdot \mathrm{mL}^{-1}\right)$ & 3.11 & 0.67 & 2.00 & 4.05 \\
Thermophilic LAB $\left(\log \mathrm{CFU} \cdot \mathrm{mL}^{-1}\right)$ & 8.43 & 0.52 & 7.49 & 8.79 \\
\hline
\end{tabular}

$\left(16.52 \pm 0.95{ }^{\circ} \mathrm{SH} .50 \mathrm{~mL}^{-1}\right)$ and $\mathrm{pH}(3.65 \pm 0.05)$ showed mean values far from those normally found at the end of natural whey starter fermentation, when it is added to the vat milk. In fact, the whey starters used in Parmigiano-Reggiano cheesemaking have $\mathrm{pH}$ around $3.20-3.30$ and a titratable acidity around $29-32{ }^{\circ} \mathrm{SH} .50 \mathrm{~mL}^{-1}$ (Formaggioni et al. 2009). $\mathrm{LAB}$ counts were $3.11 \mathrm{log} \mathrm{CFU} \cdot \mathrm{mL}^{-1}$ for mesophilic and $8.43 \mathrm{log}$ $\mathrm{CFU} \cdot \mathrm{mL}^{-1}$ for thermophilic. Therefore, an inoculum at $0.2 \%$ introduces at least 500,000 CFU. $\mathrm{mL}^{-1}$ of thermophilic LAB in milk and, obviously, more than 1 million $\mathrm{CFU} \cdot \mathrm{mL}^{-1}$ in the case of the $0.4 \%$ inoculum. Added LAB were not stressed and were in log phase of growth, as demonstrated by the high values of acidification rate, compared to values of whey starters at the end of fermentation (Reverberi et al. 2009).

Table 2 shows the main physico-chemical parameters detected in the evening milk, before and after young whey starter addition and, after creaming, in the corresponding partially skimmed milk. Whey starter addition increased, not significantly, the titratable acidity that ranged from $3.36{ }^{\circ} \mathrm{SH} .50 \mathrm{~mL}^{-1}$ (C) to 3.41 (LW) and 3.40 (HW). No significant differences were observed between the acidity of partially skimmed milk, while the increases (PS-EM) in acidity were significantly $(P<0.05)$ higher where the inoculum was greater.

$\mathrm{pH}$ of inoculated evening milk showed significantly $(P<0.05)$ lower levels compared to the control, but this difference was not significant in partially skimmed milk so as in $\mathrm{pH}$ increase (PS-EM). During maturation, the $\mathrm{pH}$ values increased, despite the increase of titratable acidity. About this, Malacarne et al. (2013) reported that the $\mathrm{pH}$ variation during the cold storage depends on two contrasting effects: (1) acidification and consequent lowering of $\mathrm{pH}$, for lactic acid production by native microbiota of the milk, and (2) release of $\mathrm{Ca}^{2+}$ from casein micelles that increases the $\mathrm{pH}$, especially at low temperatures. In this trial, the temperature of natural creaming, around $20^{\circ} \mathrm{C} \pm 1$, seems to have favoured the second aspect, as reported by Malacarne et al. (2008) studying the natural creaming at different temperatures.

As expected, the fat content has halved, reaching $1.74,1.83$ and $1.78 \mathrm{~g} .100 \mathrm{~mL}^{-1}$, in the control, in LW and in HW milk, respectively. Therefore, the inoculum did not affect the natural creaming capacity, allowing to obtain skimmed milks with a suitable fat content.

Casein content showed no significant differences among three cases, before and after natural creaming. On the other hand, natural creaming decreased impressively the SCC from more than 300,000 cells. $\mathrm{mL}^{-1}$ to values between 19,000 (HW) and 30,000 (C). The low counts of somatic cells are in accordance with the absence of changes in casein 


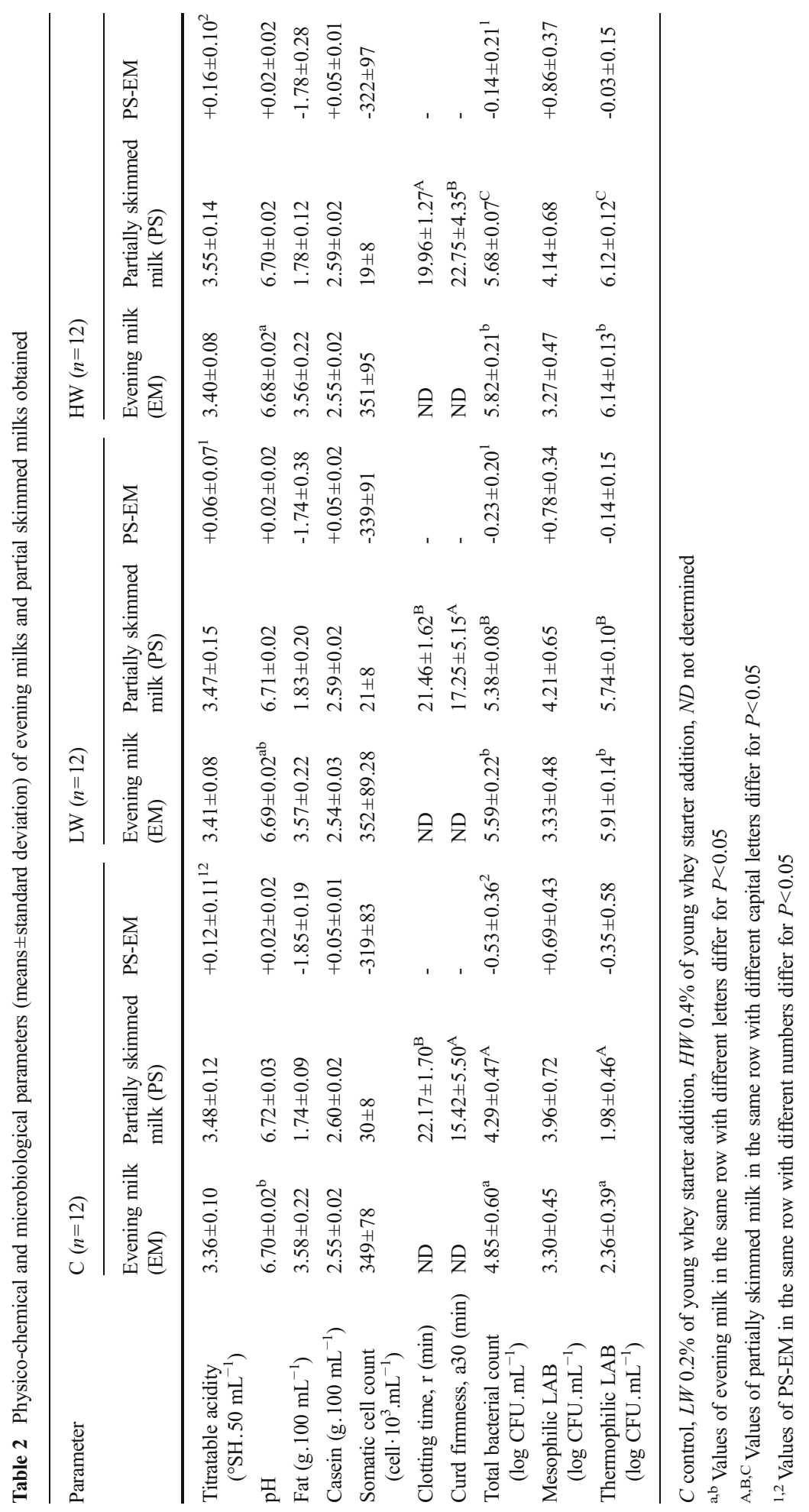


content. It is reported that more than 500,000 cells $\cdot \mathrm{mL}^{-1}$ (Malacarne et al. 2013) promote the dissociation of casein by the action of enzymes, such as plasmin (Andrews and Alichanidis 1983). The slight increase of casein content is attributable to the concentration of non-fat substance of milk during natural creaming.

Total Bacteria Counts (TBC) were, obviously, higher $(P<0.05)$ in inoculated milks due to the addition of LAB present in the young whey starter. The decrease of TBC (PS-EM), during natural creaming, was significantly more intense $(P<0.05)$ in the control milk and decreased by increasing the amount of whey starter added. The microbial growth in the inoculated milks was greater than that in the control: apparently because bacteria added with whey starter were already well adapted to the milk matrix. So, the cell growth made less apparent the cell count reduction due to adherence to the milk fat globules (Panari et al. 2007).

Mesophilic LAB counts in the evening milk remained on values around 3.30 $\log \mathrm{CFU} \cdot \mathrm{mL}^{-1}$, despite the whey starter addition. At the end of natural creaming, their number increased nearly tenfold $(1 \mathrm{log})$, in all three milks due to favourable temperature conditions. Also in this case, the number of multiplication produced cells was larger than those removed due to fat globules adhesion.

The number of thermophilic LAB increased significantly $(P<0.05)$ in inoculated milks compared to the control, by 3.55 and $3.78 \log \mathrm{CFU} \cdot \mathrm{mL}^{-1}$ for $\mathrm{LW}$ and $\mathrm{HW}$,

Table 3 Comparison of vat milk composition and cheese-making technological parameters

\begin{tabular}{|c|c|c|c|}
\hline Parameter & $\mathrm{C}(n=12)$ & LW $(n=12)$ & $\mathrm{HW}(n=12)$ \\
\hline Vat milk titratable acidity $\left({ }^{\circ} \mathrm{SH} .50 \mathrm{~mL}^{-1}\right)$ & $3.43 \pm 0.14^{\mathrm{a}}$ & $3.46 \pm 0.15^{\mathrm{a}}$ & $3.73 \pm 0.93^{\mathrm{b}}$ \\
\hline Vat milk pH & $6.71 \pm 0.02$ & $6.70 \pm 0.02$ & $6.70 \pm 0.02$ \\
\hline Clotting time, $r$ (min) & $21.8 \pm 1.4^{\mathrm{b}}$ & $21.5 \pm 1.2^{\mathrm{a}}$ & $20.7 \pm 1.3^{\mathrm{a}}$ \\
\hline Curd firmness, $a_{30}(\mathrm{~mm})$ & $15.9 \pm 4.56$ & $17.3 \pm 4.48$ & $19.50 \pm 4.52$ \\
\hline Fat $\left(\mathrm{g} .100 \mathrm{~g}^{-1}\right)$ & $2.48 \pm 0.10$ & $2.51 \pm 0.10$ & $2.50 \pm 0.11$ \\
\hline Casein $\left(\mathrm{g} .100 \mathrm{~g}^{-1}\right)$ & $2.56 \pm 0.26$ & $2.56 \pm 0.26$ & $2.56 \pm 0.26$ \\
\hline Fat/casein ratio & $0.97 \pm 0.05$ & $0.98 \pm 0.05$ & $0.98 \pm 0.05$ \\
\hline Milk acidity increase ( $\left.{ }^{\circ} \mathrm{SH} .50 \mathrm{~mL}^{-1} / 10\right)$ & 8 & 8 & 8 \\
\hline pH after whey starter addition & $6.41 \pm 0.01$ & $6.41 \pm 0.01$ & $6.40 \pm 0.01$ \\
\hline $\mathrm{pH}$ after heating & $6.39 \pm 0.01$ & $6.39 \pm 0.01$ & $6.39 \pm 0.01$ \\
\hline Heating time (s) & 300 & 300 & 300 \\
\hline Rennet added (g. $100 \mathrm{~kg}^{-1}$ milk) & 3.2 & 3.2 & 3.2 \\
\hline Temperature of renneting $\left({ }^{\circ} \mathrm{C}\right)$ & 33.1 & 33.1 & 33.1 \\
\hline Gelation time $(\mathrm{s})$ & $631 \pm 36$ & $612 \pm 32$ & $604 \pm 24$ \\
\hline Coagulum hardening time (s) & $82.86 \pm 13.85$ & $89.17 \pm 8.37$ & $76.00 \pm 16.25$ \\
\hline Duration of cutting (s) & 150 & 150 & 150 \\
\hline Curd temperature at the end of cutting $\left({ }^{\circ} \mathrm{C}\right)$ & 33.1 & 33.1 & 33.1 \\
\hline Cheese-making duration, from rennet addition to cooking end (s) & $1276 \pm 63$ & $1232 \pm 62$ & $1226 \pm 25$ \\
\hline Cooking temperature $\left({ }^{\circ} \mathrm{C}\right)$ & $54.94 \pm 0.11$ & $54.93 \pm 0.11$ & $54.93 \pm 0.11$ \\
\hline Fresh whey $\mathrm{pH}$ & $6.26 \pm 0.02$ & $6.25 \pm 0.02$ & $6.25 \pm 0.02$ \\
\hline Drain under whey (min) & $62.86 \pm 4.52$ & $61.43 \pm 3.50$ & $61.43 \pm 3.50$ \\
\hline
\end{tabular}

${ }^{\mathrm{a}, \mathrm{b}}$ Different letters in the same row indicate significant differences $(P<0.05)$ 
Table 4 Evolution of mesophilic and thermophilic lactic acid bacteria during cheese ripening $\left(\log C F U \cdot g^{-1}\right)$

\begin{tabular}{|c|c|c|c|c|c|c|}
\hline \multirow[t]{2}{*}{ Time of ripening } & \multicolumn{3}{|c|}{ Mesophilic lactic acid bacteria } & \multicolumn{3}{|c|}{ Thermophilic lactic acid bacteria } \\
\hline & $\mathrm{C}(n=12)$ & $\mathrm{LW}(n=12)$ & HW $(n=12)$ & $\mathrm{C}(n=12)$ & $\mathrm{LW}(n=12)$ & HW $(n=12)$ \\
\hline $48 \mathrm{~h}$ & $3.26 \pm 0.32^{\mathrm{a}}$ & $3.74 \pm 0.79^{\mathrm{ab}}$ & $3.28 \pm 1.01$ & $7.11 \pm 0.39^{\mathrm{c}}$ & $7.42 \pm 0.47^{\mathrm{c}}$ & $7.37 \pm 0.17^{\mathrm{b}}$ \\
\hline 7 months & $6.14 \pm 0.73^{\mathrm{b}}$ & $5.83 \pm 0.40^{\mathrm{b}}$ & $5.51 \pm 1.46$ & $5.70 \pm 0.49^{\mathrm{bc}}$ & $4.75 \pm 1.05^{\mathrm{b}}$ & $5.23 \pm 0.92^{\mathrm{ab}}$ \\
\hline 12 months & $5.21 \pm 0.63^{\mathrm{ab}}$ & $4.84 \pm 0.49^{\mathrm{b}}$ & $5.29 \pm 0.85$ & $4.59 \pm 0.83^{\mathrm{ab}}$ & $4.34 \pm 0.95^{\mathrm{b}}$ & $3.80 \pm 0.04^{\mathrm{a}}$ \\
\hline 22 months & $3.90 \pm 1.27^{\mathrm{a}}$ & $2.48 \pm 1.30^{\mathrm{a}}$ & $4.25 \pm 0.12$ & $3.20 \pm 1.17^{\mathrm{a}}$ & $1.00 \pm 0.00^{\mathrm{a}}$ & $2.89 \pm 1.64^{\mathrm{a}}$ \\
\hline
\end{tabular}

${ }^{\mathrm{a}, \mathrm{b}, \mathrm{c}}$ Different letters in the same column indicate significant differences $(P<0.05)$

respectively. In fact, these microorganisms are the main, and almost exclusive, microbial group of whey starter (Formaggioni et al. 2009). Opposite to mesophilic $\mathrm{LAB}$, the creaming temperature did not favour the thermophilic LAB growth, and their number decreased. Therefore, the adhesion prevails on the multiplication.

During natural creaming, thermophilic LAB inoculated in milk with young whey starter remained for about $12 \mathrm{~h}$ at $\mathrm{pH}$ close to neutrality, and their cells arrived in the curd in optimal conditions. In the other hand, cells of SLAB, normally added during cheesemaking with natural whey starter, are stressed for a long exposition at $\mathrm{pH}$ between 3.20 and 3.28 (De Angelis and Gobbetti 2004).

Table 3 shows vat milk composition and the cheesemaking technological parameters. $\mathrm{pH}$ and titratable acidity of vat milk reflect what was previously reported for partially skimmed milk. The acidity was significantly $(P<0.05)$ higher in HW milk, while the $\mathrm{pH}$ was slightly lower in both batches with added whey starter. The most interesting results concerned the clotting time $(r)$ and curd firmness $\left(a_{30}\right)$. The addition of whey before natural creaming clotted faster $(P<0.05)$ and was firmer compared to control. Milks inoculated had therefore a faster response to the rennet and gave a curd with a greater ability to drain off whey (Malacarne et al. 2008). This aspect has been confirmed by the technicians who always recognized the experimental milks during

Table 5 Chemical composition of cheeses at the end of ripening (22 months)

\begin{tabular}{lccc}
\hline Parameter & $\mathrm{C}(n=12)$ & $\mathrm{LW}(n=12)$ & $\mathrm{HW}(n=12)$ \\
\hline Moisture $\left(\mathrm{g} .100 \mathrm{~g}^{-1}\right)$ & 32.40 & 32.27 & 32.62 \\
Dry matter $\left(\mathrm{g} .100 \mathrm{~g}^{-1}\right)$ & 67.60 & 67.73 & 67.38 \\
Fat $\left(\mathrm{g} .100 \mathrm{~g}^{-1}\right)$ & $27.92^{\mathrm{a}}$ & $28.41^{\mathrm{b}}$ & $27.73^{\mathrm{a}}$ \\
Total nitrogen $(\mathrm{TN})\left(\mathrm{g} .100 \mathrm{~g}^{-1}\right)$ & 5.27 & 5.22 & 5.25 \\
Protein $(\mathrm{TN} \times 6.38)\left(\mathrm{g} .100 \mathrm{~g}^{-1}\right)$ & 33.63 & 33.29 & 33.48 \\
Soluble nitrogen $(\mathrm{SN})\left(\mathrm{g} .100 \mathrm{~g}^{-1}\right)$ & 1.54 & 1.54 & 1.58 \\
Ripening index $(\mathrm{SN} / \mathrm{TN} \times 100)$ & 30.51 & 30.50 & 30.73 \\
NaCl $\left(\mathrm{g} .100 \mathrm{~g}^{-1}\right)$ & 1.49 & 1.51 & 1.55 \\
Lactic acid $\left(\mathrm{g} .100 \mathrm{~g}^{-1}\right)$ & 1.51 & 1.47 & 1.51 \\
$a_{\mathrm{w}}$ & 0.906 & 0.905 & 0.905 \\
\hline
\end{tabular}

${ }^{\mathrm{a}, \mathrm{b}}$ Different letters in the same row indicate significant differences $(P<0.05)$ 
blind tests. These observations were considered very important, although empirical, because the PR cheesemaking is still guided by the cheesemaker "hand".

The fat content was slightly higher in LW milk, while casein content was similar in all three batches. Therefore, fat/casein ratio was $0.97-0.98$, considered optimal for the Parmigiano-Reggiano cheesemaking (Mariani et al. 2001).

Cheesemaking technological parameters did not show any significant difference. In particular, this was true for those parameters (amount of natural whey starter added, gelation and cooking temperature, rennet powder added, cutting time, drain under

Table 6 Sensory profile of cheeses at the end of ripening (22 months)

\begin{tabular}{|c|c|c|c|c|}
\hline Attribute & $\mathrm{C}$ & LW & HW & Significance \\
\hline Colour intensity & 3.39 & 3.30 & 3.29 & n.s. \\
\hline Appearance compliance score & $4.69^{\mathrm{a}}$ & $4.89^{\mathrm{ab}}$ & $5.10^{\mathrm{b}}$ & $* *$ \\
\hline Smell intensity & 4.00 & 4.08 & 4.00 & n.s. \\
\hline Butter smell & 2.87 & 2.87 & 2.91 & n.s. \\
\hline Rind smell & 1.82 & 1.92 & 1.76 & n.s. \\
\hline Boiled vegetable smell & 2.33 & 2.32 & 2.32 & n.s. \\
\hline Nuts smell & 2.22 & 2.18 & 2.16 & n.s. \\
\hline Negative smell & 1.72 & 1.69 & 1.68 & n.s. \\
\hline Olfactory compliance score & $4.71^{\mathrm{a}}$ & $4.89^{\mathrm{b}}$ & $4.89^{b}$ & $*$ \\
\hline Butter aroma & 3.14 & 3.13 & 3.22 & n.s. \\
\hline Rind aroma & 2.01 & 2.08 & 2.04 & n.s. \\
\hline Nuts aroma & 2.41 & 2.32 & 2.41 & n.s. \\
\hline Meat broth aroma & 2.67 & 2.58 & 2.65 & n.s. \\
\hline Nutmeg aroma & 1.91 & 1.86 & 1.87 & n.s. \\
\hline Negative aroma (propionic, butyric, pungent) & $1.95^{\mathrm{b}}$ & $1.90^{\mathrm{b}}$ & $1.78^{\mathrm{a}}$ & $*$ \\
\hline Sweet taste & 3.13 & 3.06 & 3.07 & n.s. \\
\hline Salty taste & 2.97 & 2.95 & 2.99 & n.s. \\
\hline Bitter taste & 1.79 & 1.76 & 1.82 & n.s. \\
\hline Aroma and taste compliance score & 4.71 & 4.65 & 4.77 & n.s. \\
\hline Elasticity & 2.51 & 2.46 & 2.63 & n.s. \\
\hline Friability & 3.60 & 3.62 & 3.50 & n.s. \\
\hline Moisture & 2.73 & 2.90 & 2.82 & n.s. \\
\hline Solubility & 3.92 & 4.03 & 3.99 & n.s. \\
\hline Presence of grain & 3.84 & 3.72 & 3.69 & n.s. \\
\hline Textural compliance score & 4.86 & 4.92 & 4.92 & n.s. \\
\hline Colour uniformity & 1.42 & 1.32 & 1.41 & n.s. \\
\hline Eyes/cracks number & $1.89^{\mathrm{c}}$ & $1.62^{\mathrm{b}}$ & $1.29^{\mathrm{a}}$ & $* * *$ \\
\hline Eyes/cracks size & $1.57^{\mathrm{b}}$ & $1.37^{\mathrm{a}}$ & $1.26^{\mathrm{a}}$ & $* *$ \\
\hline Presence of micro-eyes & $1.69^{\mathrm{a}}$ & $1.92^{\mathrm{b}}$ & $1.79^{\mathrm{a}}$ & $* * *$ \\
\hline
\end{tabular}

n.s. not significant

$* P<0.05 ; * * P<0.01 ; * * * P<0.001$

a,b,c Different letters in the same row indicate significant differences 
whey) decided by the cheesemaker experience. The improved rheological parameters of experimentals milks shortened processing times: In particular, the gelation time decreased $19 \mathrm{~s}$ in LW and $27 \mathrm{~s}$ in HW thesis. The cheesemaking duration decreased by 44 and $50 \mathrm{~s}$, respectively, due to both reduction of gelation time and cooking time. The reduction of processing times was related to the amount of whey starter and rennet added to optimize the properties of the curd (Mucchettti et al. 2014).

Table 4 presents the thermophilic and mesophilic LAB count of the cheeses at $48 \mathrm{~h}$ and after 7, 12, and 22 months of ripening. According to the results, only ripening time affected them significantly. Mesophilic LAB reached their maximum growth in the seventh month of ripening for all the theses, while the thermophilic LAB showed the highest levels at the beginning and then gradually decreased. These results are in agreement with the observation reported in other studies (Coppola et al. 1997; Gatti et al. 2008). The results of the present study show that the addition of LAB during natural creaming of milk using young whey starter does not affect the normal succession of thermophilic and mesophilic LAB in the cheese, and their counts in different stages of ripening is typical for Parmigiano-Reggiano cheese (Coppola et al. 1997 and 2000; Gatti et al. 2008; Neviani et al. 2009).

At the end of ripening ( 22 months), in addition to the microbiological analyses, chemical and sensory analyses were carried out. In all the three cheeses, the chemical parameters reported (Table 5) were in agreement with other reports (Tosi et al. 2008; Gatti et al. 2014). Among the three batches, no significant differences $(P<0.05)$ were found, except for the fat content, which varied according to variation observed in partially skimmed milk of Table 1 .

Table 6 shows the values of the average intensity perceived by assessors for each descriptor and statistically significant differences determined by ANOVA. The increase of the addition of young natural whey starter led to an increase of appearance $(P<0.01)$ and olfactory $(P<0.05)$ compliance scores, while the negative aromas, mainly of propionic, butyric and pungent, decreased $(P<0.05)$. Moreover, the addition of natural whey starter led to a decrease of the eyes and cracks both in the number $(P<0.001)$ and in the size $(P<0.01)$. This can be assigned to the improvement of curd draining (Malacarne et al. 2008) and to fast acidification by unstressed thermophilic LAB (Coppola et al. 2000; De Angelis and Gobbetti 2004) The presence of micro-eyes, which is not a defect, was highest $(P<0.001)$ in the cheese coming from milk with $0.2 \%$ of whey starter addition.

\section{Conclusions}

The addition of young whey starter in the evening milk for Parmigiano-Reggiano cheesemaking is a thermophilic LAB inoculum, which, during natural creaming, remains almost mostly in partially skimmed milk. LAB can grow readily in the curd, because they have not been stressed by the low $\mathrm{pH}$ that naturally occurs in the last stages of whey starter fermentation. Also, the small quantity of lactic acid added in milk through the addition of young whey starter has been considered important for maturation of the milk, replacing the limited activity of mesophilic LAB. The limited amount of lactic acid added is enough to improve the main rheological parameters, as also perceived by the technicians and the cheesemakers evaluating in blind. From the sensory point of view, a positive influence of the addition of natural whey starter on 
appearance compliance score is resulted, mainly due to the decrease both in the number and in size of eyes and cracks. A favourable effect, attributable to the addition of natural whey starter, is also observed on olfactory compliance score.

The positive effects determinated by young whey starter addition justify the adoption of this practice to innovate Parmigiano-Reggiano cheesemaking, according to Production Specification.

Acknowledgments This research was funded by Regione Emilia-Romagna (Italy) within the project " $P-R$ tradizione e innovazione, verifica delle caratteristiche tipiche del prodotto a seguito dell'introduzione di innovazioni tecnologiche nel processo di produzione del formaggio Parmigiano-Reggiano". The authors wish to thank Mr. Oriano Carretti, cheesemaker of Caseificio Sant'Angelo, San Giovanni in Persiceto (BO), Italy, for information regarding the technique of addition of the whey starter that inspired this work and that he uses since a long time.

\section{References}

Andrews AT, Alichanidis E (1983) Proteolysis of caseins and the proteosepeptone fraction of bovine milk. J Dairy Res 50:275-290

Annibaldi S, Ferri G, Mora R (1977) Nuovo orientamenti nella valutazione tecnica del latte: tipizzazione lattodinamografica [New trends for milk technical evaluation: lactodynamographic standardisation]. Sci Tec Latt Cas 28:115-126

Biggs DA (1978) Instrumental infrared estimation of fat, protein, and lactose in milk: collaborative study. J Assoc Off Anal Chem 61:1015-1034

Coppola R, Nanni M, Iorizzo M, Sorrentino A, Sorrentino E, Grazia L (1997) Survey of lactic acid bacteria isolated during the advanced stages of the ripening of Parmigiano Reggiano cheeses. J Dairy Res 64:305-310

Coppola R, Nanni M, Iorizzo M, Sorrentino A, Sorrentino E, Chiavari C, Grazia L (2000) Microbiological characteristics of Parmigiano Reggiano cheese during the cheesemaking and the first months of the ripening. Lait 80:479-490

De Angelis M, Gobbetti M (2004) Enviromental stress response in lactobacillus: a review. Proteomics 4:106-122

Desmazeaud M (1984) The maturation of milk. In: Eck A (ed) Le fromage. Lavoiser, Paris, pp 175-178

EU (2004) Regulation (EC) No 853/2004 of the European parliament and of the council of 29 April 2004 laying down specific hygiene rules for on the hygiene of foodstuffs. Off J Eur Union 30/04/2004, L 139/55

EU (2011) Commission regulation (EU) No 794/2011 of 8 August 2011 approving amendments to the specification for a name entered in the register of protected designations of origin and protected geographical indications (Parmigiano Reggiano (PDO). Off J Eur Union L 204/19

Formaggioni P, Vecchia P, Summer A, Franceschi P, Malacarne M, Mariani P (2009) Natural wheystarter in the Parmigiano-Reggiano cheese production, with particular reference to the acidification of the wheel in the early hours after the extraction from the vat: an overview. Ann Fac Medic Vet Di Parma 39:141-152

Gatti M, De Dea LJ, De Lorentiis A, Bottari B, Santarelli M, Bernini V, Neviani E (2008) Dynamics of whole and lysed bacterial cells during Parmigiano- Reggiano cheese production and ripening. Appl Environ Microbiol 74(19):6161-6167

Gatti M, Bottari B, Lazzi C, Neviani E, Mucchetti G (2014) Microbial evolution in raw-milk, long-ripened cheeses produced using undefined whey starters. J Dairy Sci 97:573-591

Gripon JC, Desmazeaud MJ, Le Bars D, Bergere JL (1975) Etude du rôle des micro-organismes et des enzymes au cours de la maturation des fromages. Lait 55:502-516

IDF 4A (1982) Cheese and processed cheese-Determination of total solids content (Reference method). IDF, Brussels, Belgium

IDF 88A (1988) Cheese and processed cheese-Determination of chloride content (Potentiometric titration method). IDF, Brussels, Belgium

ISO 8586-1:1993 (1993) Sensory analysis - general guidance for the selection, training and monitoring of assessors - part 1: selected assessors. International Organisation for Standardisation, Geneva

ISO 8586-2:1994 (1994) Sensory analysis - general guidance for the selection, training and monitoring of assessors -part 2: experts. International Organisation for Standardisation, Geneva 
Malacarne M, Summer A, Formaggioni P, Franceschi P, Sandri S, Pecorari M, Vecchia P, Mariani P (2008) Dairy maturation of milk used in the manufacture of Parmigiano-Reggiano cheese: effects on physicochemical characteristics, rennet-coagulation aptitude and rheological properties. J Dairy Res 75:218-224

Malacarne M, Summer A, Franceschi P, Formaggioni P, Pecorari M, Panari G, Vecchia P, Sandri S, Scotti C, Mariani P (2013) Effects of storage conditions on physico-chemical characteristics, salt equilibria, processing properties and microbial development of raw milk. Int Dairy J 29:36-41

Mariani P, Summer A, Formaggioni P, Malacarne M, Battistotti B (2001) Rilievi sui principali requisiti tecnologico-caseari del latte per la produzione di formaggio grana [Remarks about the main dairytecnological requisites of milk for grana cheese production]. Sci Tec Latt Cas 52:49-91

Mucchettti G, Gatti M, Nocetti M, Reverberi P, Bianchi A, Galati F, Petroni A (2014) Segmentation of Parmigiano Reggiano dairies according to cheese-making technology and relationships with the aspect of the cheese curd surface at the moment of its extraction from the cheese vat. J Dairy Sci 97:1202-1209

Neviani E, De Dea LJ, Bernini V, Gatti M (2009) Recovery and differentiation of long ripened cheese microflora through a new cheese-based cultural medium. Food Microbiol 26:240-245

Panari G, Reverberi P, Caroli A, Nocetti M, Pecorari M (2007) Le variazioni del profilo microbiologico del latte durante l'affioramento in diverse condizioni operative [Changes in the microbiological characteristics of the milk during the gravity separation of fat in different work conditions]. Sci Tec Latt Cas 58:83-93

Pecorari M, Panari G (2005) La produzione di Parmigiano-Reggiano tra innovazione e tradizione [Parmigiano-Reggiano production between innovation and tradition]. Sci Tec Latt Cas 56:85-103

Reverberi P, Gambini G, Caroli A, Pecorari A, Nocetti M (2009) Profilo dei siero-innesti per ParmigianoReggiano e modalità analitiche di valutazione [Profile and analytical valuation of Parmigiano-Reggiano whey starters]. Sci Tec Latt Cas 60:37-42

Sacchetti M, Zambonelli C (1963) Acidità e carico microbico nei sieri-innesto della zona tipica del "Parmigiano-Reggiano" [Acidity and microbial count of whey starter from tipical area of ParmigianoReggiano cheese]. Il Latte 37:351-360

Savini E (1946) Analisi del latte e dei latticini. Hoepli, Milan

Schmidt-Madsen P (1975) Fluoro-opto-electronic cell-counting on milk. J Dairy Res 42:227-239

Tosi F, Sandri S, Tedeschi G, Malacarne M, Fossa E (2008) Variazioni di composizione e proprietà fisicochimiche del Parmigiano-Reggiano durante la maturazione e in differenti zone della forma. [Variations of composition and physico-chemical properties of Parmigiano-Reggiano cheese throghout ripening in different zones of the cheese wheel]. Sci Tec Latt Cas 59:507-528

UNI EN ISO 13299:2010 (2010) Sensory analysis - methodology_general guidance for establishing a sensory profile (ISO 13299:2003). Ente Italiano di Normazione, Milan

UNI EN ISO 8589:2010 (2010) Sensory analysis_-general guidance for the design of test rooms (ISO 8589: 2007). Ente Italiano di Normazione, Milan

www.parmigianoreggiano.it Disciplinare di produzione del formaggio Parmigiano Reggiano http://www. parmigianoreggianoit/consorzio/disciplinare_produzione_vigente_2011/defaultaspx, Accessed 2 April 2015 